\title{
A new axiid (Crustacea: Decapoda: Axiidea) from the Neogene of Belgium and the Netherlands
}

\author{
René H.B. Fraaije, Barry W.M. van Bakel, John W.M. Jagt and Frederik H. Mollen
}

With 4 figures and 1 table

FraAiJe, R. H. B., VAN BAKel, B. W. M., JAGT, J. W. M. \& Mollen, F. H. (2011): A new axiid (Crustacea: Decapoda: Axiidea) from the Neogene of Belgium and the Netherlands. - N. Jb. Geol. Paläont. Abh., 260: 157-163. Styttgart.

Abstract: From small phosphatic nodules in sandy deposits of Neogene age, previously excavated at Emblem (northwest Belgium) and currently suction dredged at Langenboom (southeast Netherlands), several chelipeds as well as fragments of carapace and abdomen of an axiid shrimp have been collected. These remains are here described as a new genus and species, which constitute the first record of the family Axiidae from Neogene strata in the North Sea Basin and the second species to be reported from Pliocene strata worldwide.

Key words: Crustacea, Axiidae, Neogene, taxonomy, Belgium, The Netherlands.

\section{Introduction}

At present, 24 extant genera are assigned to the family Axiidae HuXley, 1879 (De Grave et al. 2009; KoMAI et al. 2010). Habitats of these burrowing shrimps range from littoral to abyssal environments, down to 1,788 metres depth (SAKAI 1994). There are very few records of fossil species referable to the genus Axius LEACH, 1816, although there are quite a number of extinct genera which are currently assigned to the family (see SCHWEITZER et al. 2010: 42). Usually only portions of the first pereiopods and, more rarely, of the carapace are available for fossil species (cf. BISHOP \&
WiLLIAMS 2005) which makes a diagnostic comparison with extant species and thorough identification almost impossible.

From sandy deposits of Neogene age in northwest Belgium and the southeast Netherlands (Fig. 1) about two dozen right and left first pereiopods and a few carapace and abdominal remains have been collected to date. These specimens occur in small phosphatic nodules and are comparatively well preserved. They have previously been tentatively referred to as Calliax $\mathrm{n}$. sp. (VAn Bakel et al. 2006: 371) or as Axius sp. (FraAuJe et al. 2007: 38; JAGT et al. 2007: 199). 


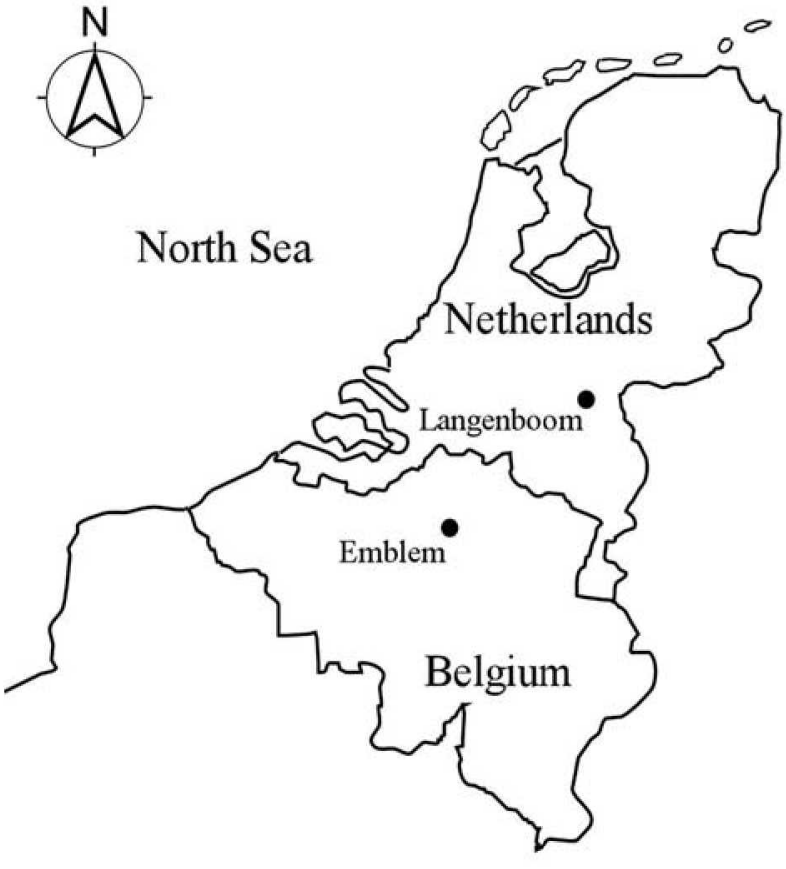

Fig. 1. Schematic map of Belgium and the Netherlands, showing the localities of Emblem and Langenboom.

\section{Systematic palaeontology}

Institutional abbreviations: IRScNB - Institut royal des Sciences naturelles de Belgique, Brussels, Belgium; MAB Oertijdmuseum De Groene Poort, Boxtel, the Netherlands; USNM - United States National Museum, Washington DC.

Order Decapoda LATREILLe, 1802

Infraorder Axiidea DE SAint Laurent, 1979

Family Axiidae Huxley, 1879

\section{Genus Plioaxius nov.}

Type species: Plioaxius lineadactylus n. sp.

Etymology: Alluding to the stratigraphical occurrence of this axiid.

Diagnosis: Carapace smooth, dorsal surface strongly convex, carinate in anterior half. Cervical groove well developed, reaching anteroventrally to hepatic region. Antero- lateral margins smooth. Pereiopods 1 clearly unequal and devoid of spines, major claw with large, subrectangular palm and short, robust fingers; minor claw with very small, subrectangular palm and much longer, curved fingers; fingers of both chelipeds grooved.

\section{Plioaxius lineadactylus n. sp.} Figs. 2-3

Etymology: Named after the extremely straight and elongated fixed finger of the minor cheliped.

Types: Holotype (MAB k. 3021), a carapace measuring 22 $\mathrm{mm}$ in length and $11 \mathrm{~mm}$ in width, with associated imprints of major and minor cheliped, from Emblem, Belgium; paratypes (MAB k. 3022-3029), six short-fingered (major) chelae and two long-fingered (minor) chelae, all from Emblem, as well as paratypes (MAB k. 3030-3045), ten shortfingered major chelae, five long-fingered minor chelae and a partially preserved abdomen, all from Langenboom, the Netherlands.

Table 1. List of gastropods and bivalves associated with type specimens of Plioaxius lineadactylus n. gen., n. sp. from Emblem, indicative of an early Pliocene age (WESSELINGH 2002; see also MoerdiJk et al. 2010).

Galeodea cf. bicatenata (J. SowERBY, 1817)

Scaphella cf. lamberti (J. Sowerby, 1816)

Glycymeris obovata subsp.

Pecten grandis J. DE C. Sowerby, 1829

Cardiidae sp. indet.

Acanthocardia cf. echinata (LinNAEUs, 1758)

Spisula ?arcuata (J. Sowerby, 1817)

Ensis sp.

Pygocardia rustica forma tumida (NYST, 1835)

Glossus cf. humanus (Linnaeus, 1758)

Panopea cf. faujasi MéNARd de LA GroYe, 1807

Panopea sp.

Type locality and horizon: A set of fossiliferous phosphatic nodules from Emblem, which yielded the holotype and paratypes MAB k. 3022-3029, were collected in the $1970 \mathrm{~s}$ and 1980 s by LuC VAN HerCK, EMmanuel and Goedele Verreydt and Frederik Mollen from a local sand dump left after maintenance dredging works in the 1960s along

Fig. 2. A-G - Plioaxius lineadactylus n. gen., n. sp., lower Pliocene, Emblem, Belgium. A-C: Holotype (MAB k. 3021) carapace with imprints of major and minor chelae; D, F, G: paratypes (MAB k. 3022-3023) minor chelae; E: paratype (MAB 3024) major chela. Scale bars equal $10 \mathrm{~mm}$. 

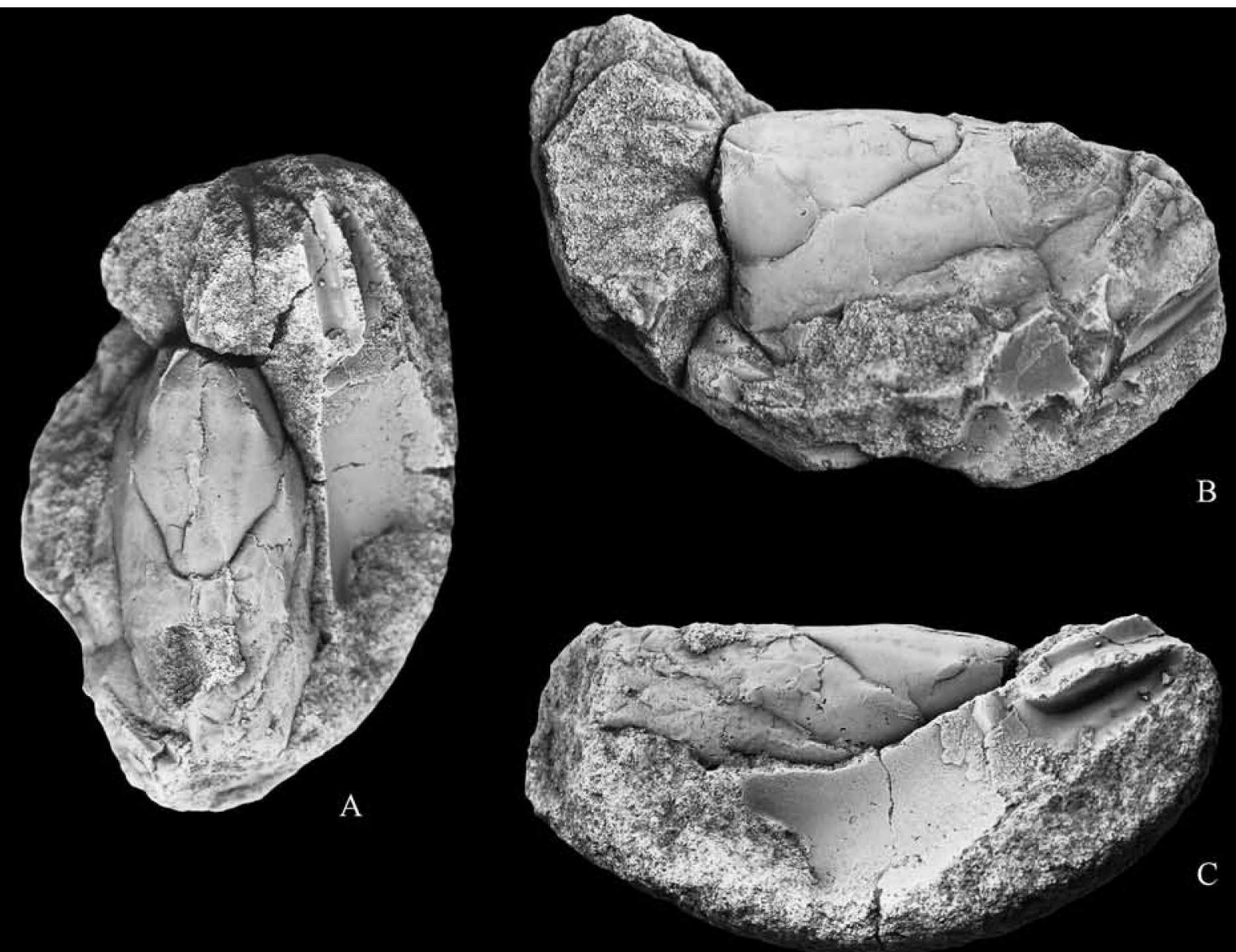

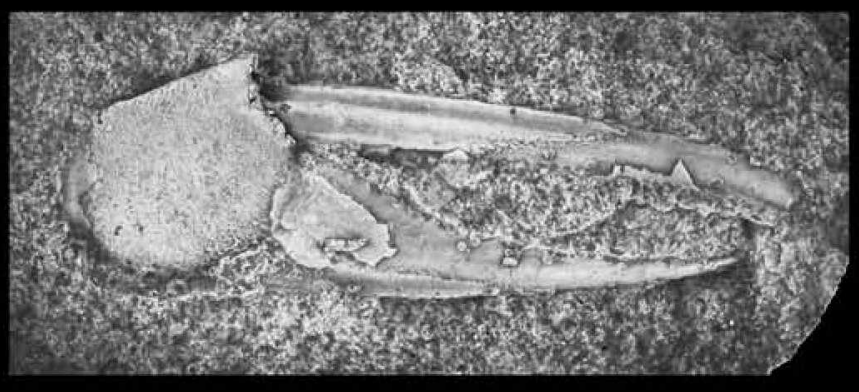

D

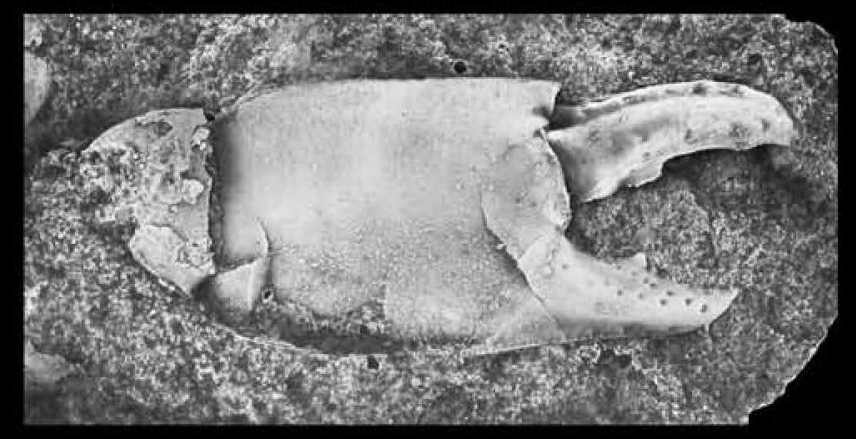

(A-E)

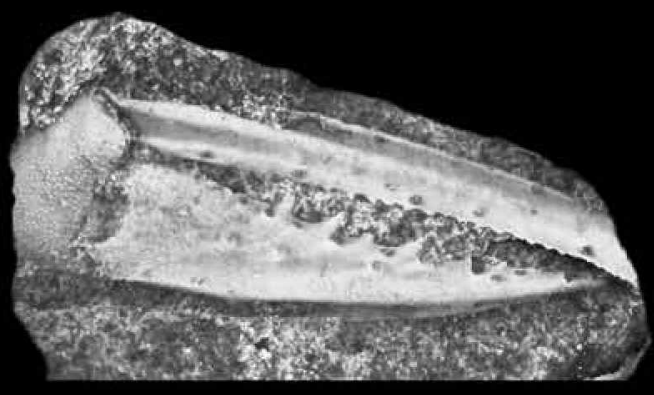

(F-G)

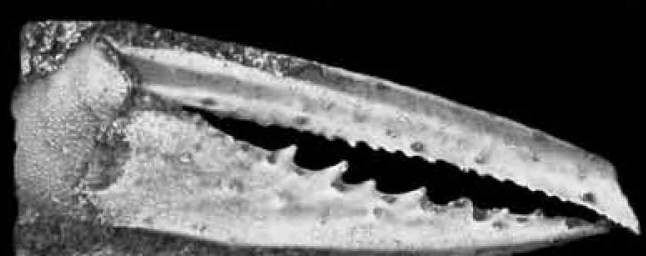

Fig. 2. 

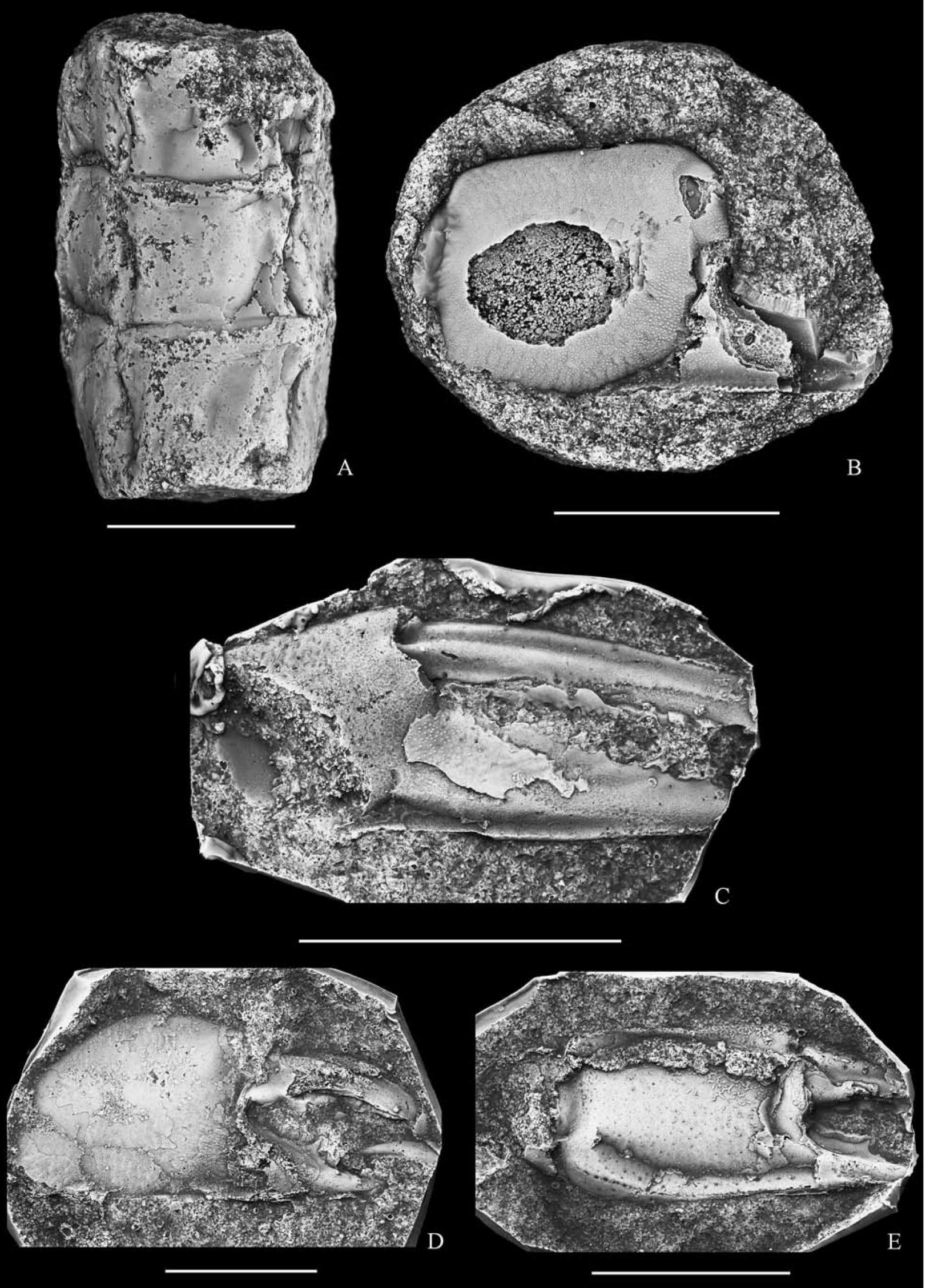

Fig. 3 
the Netekanaal (section Emblem yacht harbour; Viersel lock). This site is located southwest of Emblem (Lambert co-ordinates: $\mathrm{x}-165.85, \mathrm{y}-204.95$ ), a hamlet within the municipality of Ranst (province of Antwerp, Belgium). According to the geological map of Belgium (ScHiltz et al. 1993), the SSW and NNE parts of that particular section of the Netekanaal are situated in the Antwerpen Sands (Berchem Formation) and Diest Sands (Diest Formation), respectively, both immediately underlying the Quaternary. But, on the basis of the accompanying molluscan fauna found in the same set of nodules (species identified by $\mathrm{Dr}$ F.P. Wesselingh, Nederlands Centrum voor Biodiversiteit [Naturalis], Leiden, the Netherlands), the material was dated as early Pliocene. This can be explained by the presence of Quaternary frost fissures filled up with reworked material from the Pliocene that sporadically occurs in the area of the locality (M. Bosselaers, pers, comm., 2009). Although the vast majority of the molluscan material (see Table 1) is poorly preserved, making many identifications uncertain, the Emblem fauna appears to be of early Pliocene age, based on the presence of Pygocardia rustica forma tumida. Typically Miocene species, such as Venus multilamella LAMARCK, 1818 and Anadara diluvia LAMARCK, 1805 were not found in this assemblage. Various moulds of articulated bivalve specimens were seen, indicating that at least part of this lot was preserved in situ. The fauna comprises both (deep-) burrowers in sand and silt (such as Panopea spp. and Ensis), as well as shallow burrowers or bottom dwellers, such as Pecten.

The material from Langenboom comprises a set of fossiliferous phosphatic nodules, which yielded paratypes MAB k. 3031-3045, collected by Peter MARkies, René van Neer, Olaf Vermeulen, Cor de Visser, Hans WijnsteKERS and the senior author, from the Langenboom sandpit (WIJNKer et al. 2008; KLOMPMAKER 2009; VAN BAKEL et al. 2009) in the province of Noord-Brabant, the Netherlands. The stratigraphy of this locality was discussed in detail by WIJNKER et al. (2008), to which paper reference is made. The level which produced these phosphatic nodules with decapod remains is within Unit B of the Oosterhout Formation, which has been dated as Zanclean to early Piacenzian, indicating a slightly younger age for the material from Langenboom in comparison to the Emblem faunule.

Description: Carapace smooth, dorsal surface strongly convex, unornamented median anterogastric carina in anterior half; faint, short, unornamented submedian supraorbital carinae. Cervical groove well developed, reaching anteroventrally to hepatic region. Anterolateral margins smooth. Pereiopods 1 clearly unequal and devoid of spines; major one with short, curved dactylus and fixed finger, both with a

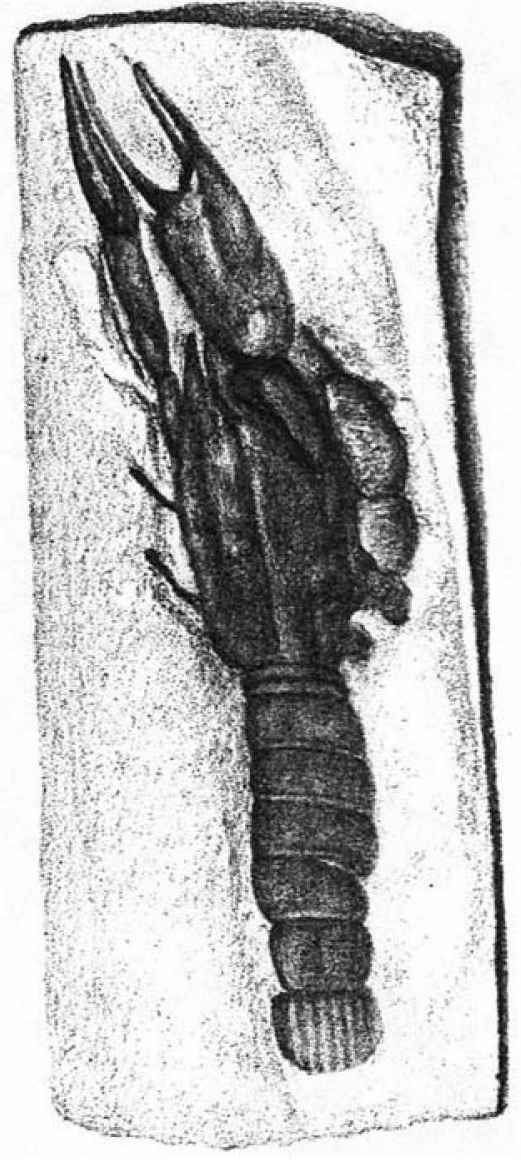

Fig. 4. Electronic copy of the original illustration of Axius fontannesi A. Milne-Edwards in Fontannes, 1885 (pl. 1, fig. 2), Pliocene, Département Drôme, southern France.

single tooth just proximal to midlength; the minor one with extremely long, straight, sharp-pointed dactylus and long, curved fixed finger; dactylus substantially longer than fixed finger and cutting edge with c. 25 more or less equal-sized, forwardly directed denticles; cutting edge of moderately curved and tapering fixed finger with about eight forwardly directed teeth. Fingers of both chelipeds grooved. Palm of minor claw subrectangular; maximum length about 40 per

Fig. 3. A-E - Plioaxius lineadactylus n. gen., n. sp., all from Unit B (Oosterhout Formation, Zanclean to early Piacenzian) at Langenboom, the Netherlands. A: Paratype (MAB k. 3030) partially preserved abdomen; B, D, E: paratypes (MAB k. 3031-3033) major chelae; C: paratype (MAB k. 3034) minor chela. Scale bars equal $10 \mathrm{~mm}$. 
cent of that of dactylus of minor claw. Palm of major claw elongated, maximum length about 150 per cent of that of dactylus of major claw.

Discussion: Plioaxius lineadactylus n. gen., n. sp. differs from all other known fossil and extant axiids (see e.g., Sakai \& de Saint Laurent 1989; Dworschak 1992; KensLEY 2003; NGOC-Ho 2003, 2005, 2006; LiN 2006; HEARD et al. 2007; SCHWEIGERT 2009; SCHWEITZER et al. 2010) in being strongly heterochelate, having a minor cheliped with a very short palm (relative to dactylus) and chelipeds without pronounced spines at upper and lower margins.

To date, only three remains of axiids of Paleogene age have been recorded. Of these Axiopsis eximia KENSLEY \& Williams, 1990 from the mid-Eocene of South Carolina, USA, is by far the most completely preserved. The holotype (USNM 219431) is nearly complete, albeit distorted and silicified, lacking only some distal portions of appendages (Kensley \& Williams 1990, figs. 3-4). Interestingly, the co-occurrence of this species with molluscan taxa such as Cardiidae, 'Corbula', Turritella and Dentalium indicates a palaeoenvironment which is closely comparable to that of Plioaxius lineadactylus n. gen., n. sp. from Langenboom. At that locality, the following decapod crustacean genera co-occur with the new axiid: Cancer, Harenacorystes, Corystes, Ebalia, Maja, Liocarcinus and Pagurus (FRAAIJE et al. 2007: 38, table 1). Those authors (FraAje et al. 2007) also listed Callianassa subterranea (MonTAGu, 1808), but upon closer inspection it has now been determined that these specimens actually represent the 'crusher' pereiopods of Plioaxius n. gen.

A partially preserved axiid carapace from the lower Oligocene of Kyushu, Japan, was described by KARASAwA \& Fudous (2000: 242, fig. 3). However, in view of poor preservation, this was placed only provisionally in Axius (s.1.). Another Oligocene record is that of Axius reticulatus by Rathbun (1919) from Panama, which is represented by a single, incomplete chela and its true systematic position is at least doubtful (KenSLEY \& WILLIAMS 1990; KARASAWA \& Fudouj 2000). From Pliocene deposits only a single species has been recorded previously. A. MiLne-EDWARDS (in FONTANNES 1885: 425-429, pl. 1, fig. 2) described and named Axius fontannesi (Fig. 4) from the 'Marnes pliocènes à Brissopsis', near the village of Eurre, Département Drôme (Rhône-Alpes, southern France). This species differs considerably from Plioaxius lineadactylus n. gen., n. sp. in having subequal chelae.

\section{Acknowledgements}

For collection and donation of and supply of stratigraphical data on the Belgian material, we thank M. BosselAERs (Berchem), J. Herman (Beigem), L. Van Herck (Booischot), E. Verreydt (Berlaar), G. Verreydt (Bonheiden) and E. WILLE (Fontin/Wuustwezel-Gooreind). For supply of the Dutch material, we are grateful to P. MARKIES, R. van NEER, F. and R. Reiss, O. Vermeulen, C. DE Visser and H. WiJnSTEKERS. Dr F.P. Wesselingh, Nederlands Centrum voor Biodiversiteit [Naturalis], Leiden, the Netherlands, provided valuable support in identifying the molluscan fauna, and $\mathrm{H}$. KARASAWA is thanked for providing items of literature.

\section{References}

Bishop, G.A. \& Williams, A.B. (2005): Taphonomy and preservation of burrowing thalassinidean shrimps. Proceedings of the Biological Society of Washington, 118: 218-236.

De Grave, S., Pentcheff, N.D., Ahyong, S.T., Chan, T.Y., Crandall, K.A., Dworschak, P. C., Felder, D.L., Feldmann, R.M., Fransen, C.H.J.M., Goulding, L.Y.D., Lemaitre, R., Low, M.E.Y., Martin, J.W., Ng, P.K.L., Schweitzer, C.E., TAn, S.H., Tshudy, D. \& Wetzer, R. (2010): A classification of living and fossil genera of decapod crustaceans. - The Raffles Bulletin of Zoology, Supplement, 21: 1-109.

DwOrSCHAK, P.C. (1992): The Thalassinidea in the Museum of Natural History, Vienna; with some remarks on the biology of the species. - Annales des Naturhistorischen Museums in Wien, 93B: 189-238.

FonTANNES, F. (1885): Nouvelle contribution à la faune et à la flore des marnes pliocènes à Brissopsis d'Eurre (Drôme). - Annales de la Société d'Agriculture, d'Histoire Naturelle et des Arts Utiles de Lyon, (5) 6: 421-436.

FraAiJe, R.H.B., VAN BAKEL, B.W.M. \& JAGT, J.W.M. (2007): A new species of Goniocypoda and the first record of Glyphithyreus wetherelli (BELL, 1858) (Decapoda, Brachyura) from the Eocene of Nieuwvliet-Bad, The Netherlands. - In: Garassino, A., Feldmann, R.M. \& Teruzzi, G. (Eds): 3rd Symposium on Mesozoic and Cenozoic decapods crustaceans. Museo di Storia naturale di Milano, May 23-25, 2007. - Memorie della Società Italiana di Scienze Naturali e del Museo Civico di Storia Naturale di Milano, 35: 37-42.

Heard, R.W., King, R.A., Knott, D.M., Thoma, B.P. \& ThORnTOn-DeVictor, S. (2007): A guide to the Thalassinidea (Crustacea: Malacostraca: Decapoda) of the South Atlantic Bight. - NOAA Professional Paper NMFS, 8: iii $+1-30$.

HuxLEy, T.H. (1879): On the classification and the distribution of the crayfishes. - Proceedings of the Scientific Meetings of the Zoological Society of London, 1878: $752-788$.

JAGT, J.W.M., van BAKel, B.W.M. \& FraAiJe, R.H.B. (2007): Post-Paleocene ghost shrimps, lobsters and crabs from Belgium: an update. - Geologica Belgica, 10: 199-200.

Karasawa, H. \& Fudouj, Y. (2000): Palaeogene decapod Crustacea from the Kishima and Okinoshima groups, Kyushu, Japan. - Paleontological Research, 4: 239-253.

Kensley, B. (2003): Axioid shrimps from Guam (Crustacea, Decapoda, Thalassinidea). - Micronesica, 35-36: 359384.

Kensley, B. \& Williams, A.B. (1999): Axiopsis eximia, a new thalassinidean shrimp (Crustacea, Decapoda, Axiidae) from the Middle Eocene of South Carolina. - Journal of Paleontology, 64: 798-802.

KLOMPMAKER, A.A. (2009): Taphonomic bias on drill-hole predation intensities and paleoecology of Pliocene molluscs from Langenboom (Mill), the Netherlands. - Palaios, 24: 772-779.

Komal, T., Lin, F.-J. \& Chan, T.-Y. (2010): Five new species of Axiidae (Crustacea: Decapoda: Axiidea) from deep-water off Taiwan, with description of a new genus. - Zootaxa, 2352: 1-28. 
LAMARCK, J.B. DE (1805): Mémoires sur les fossiles des environs de Paris. - Annales du Muséum d'Histoire naturelle de Paris, 5: 28-36, 91-98, 179-188, 237-245, 349-357.

LAMARCK, J.B. DE (1818): Histoire naturelle des animaux sans vertèbres, 5: 1-612.

LATREILlE, P.A. (1802): Histoire naturelle, générale et particulière, des crustacés et des insectes, 3: 1-408; Paris (Dufart).

LEACH, W.E. (1816): A tabular view of the external characters of four classes of animal which Linné arranged under Insecta: with the distribution of the genera composing three of these classes into orders and c. and descriptions of several new genera and species. - Transactions of the Linnean Society of London, 11: 306-400.

Lin, F.-J. (2006): Two new axioids (Decapoda: Thalassinidea) from New Caledonia. - Journal of Crustacean Biology, 26: 234-241.

LinnaEus, C. (1758): Systema naturae (10th edition), 1: 1-824; Holmiae (Laurentii Salvii).

Ménard de LA Groye, F.J.B. (1807): Mémoire sur un nouveau genre de coquille de la famille des Solénoides (Panopea). - Annales du Muséum d'Histoire naturelle de Paris, 9: 131-139.

Moerdijk, P., Janssen, A.W., Wesselingh, F.P., Peeters, G.A., Pouwer, R., Van Nieulande, F. A.D., Janse, A.C., VAn der Slik, L., Meijer, T., Rijken, R., Cadée, G.C., Hoeksema, D., Doeksen, G., BastemeiJer, A., Strack, H., Vervoenen, M. \& Ter Poorten, J.J. (2010): Geologie van Nederland. De fossiele schelpen van de Nederlandse kust. - 332 pp.; Leiden (NCB Naturalis).

Montagu, G. (1808): Supplement to Testacea Britannica with additional plates. $-\mathrm{v}+183$ pp.; Exeter (Woolmer).

NGoc-Ho, N. (2003): European and Mediterranean Thalassinidea (Crustacea, Decapoda). - Zoosystema, 25: 439-555.

NGoC-Ho, N. (2005): Thalassinidea (Crustacea, Decapoda) from French Polynesia. - Zoosystema, 27: 47-83.

NGoc-Ho, N. (2006): Three species of Acanthaxius SAKAI \& DE Saint Laurent, 1989, including two new to science, from the Solomon Islands and New Caledonia (Crustacea, Thalassinidea, Axiidae). - Zootaxa, 1240: 57-68.

Nyst, P. (1835): Recherches sur les coquilles fossiles de la province d'Anvers. - iii + 66 pp.; Bruxelles (Perichon).

Rathbun, M.J. (1919): Decapod crustaceans from the Panama region. - United States National Museum Bulletin, 103: $123-184$.

Saint Laurent, M. de (1979): Vers une nouvelle classification des Crustacés Décapodes Reptantia. - Bulletin de l'Office National des Pêches de la République Tunisienne, Ministère de l'Agriculture, 3: 15-31.

SAKAI, K. (1994): Eleven species of Australian Axiidae (Crustacea: Decapoda: Thalassinidae) with descriptions of one new genus and five new species. - The Beagle, 11: $175-202$.

SaKai, K. \& de Saint Laurent, M. (1989): A check list of Axiidae (Decapoda, Crustacea, Thalassinidea, Anomula), with remarks and in addition descriptions of one new subfamily, eleven new genera and two new species. - Naturalists, 3: 1-100.

Schiltz, M., Vandenberghe, N. \& Gullentops, F. (1993): Geologische kaart van België, Vlaams Gewest, Kaartblad
(16), Lier, Schaal 1:50 000. - Brussels (Ministerie van Economische Zaken, Belgische Geologische Dienst).

Schweigert, G. (2009): New genera and species of "thalassinideans" (Crustacea: Decapoda: Axiidea, Gebiidea) from the Upper Jurassic of Eichstätt and Brunn (S Germany). - Archaeopteryx, 27: 21-30.

Schweitzer, C.E., Feldmann, R.M., Garassino, A., Karasawa, H. \& Schweigert, G. (2010): Systematic list of fossil decapod crustacean species. - Crustaceana Monographs, 10: 1-230.

Sowerby, J. (1816-1817): The mineral conchology of Great Britain. - Pls. 115-150 (1816); pls. 151-186 (1817); London (published by the author).

Sowerby, J. DE C. (1829): The mineral conchology of Great Britain. - Pls. 581-597; London (published by the author).

VAN BAKEL, B.W.M., FRAAIJE, R.H.B. \& JAGT, J.W.M. (2006): Synopsis of Cenozoic decapod crustaceans from Belgium. - Revista Mexicana de Ciencias Geológicas, 23: 370-374.

VAn Bakel, B.W.M., JaGt, J.W.M., Artal, P. \& FraAiJe, R.H.B. (2009): Harenacorystes johanjansseni, a new Pliocene crab (Crustacea, Decapoda) from the Netherlands, and notes on Miocene-Pliocene corystoid crabs from the North Sea Basin. - Bulletin of the Mizunami Fossil Museum, 35: 79-85.

Wesselingh, F.P. (2002): On a Pliocene faunule from Oelegem, Belgium. - Nationaal Natuurhistorisch Museum, Department of Cainozoic Mollusca, Internal Report, 168: 1-4 (unpublished).

Wijnker, E., Bor, T.J., Wesselingh, F.P., Brinkhuis, H., Burger, A.W., Vonhof, H.B., Post, K., Hoedemakers, K., Janse, A.C. \& Taverne, N. (2008): Neogene stratigraphy of the Langenboom locality (Noord-Brabant, the Netherlands). - Netherlands Journal of Geosciences, 87 : 165-180.

Manuscript received: July 1st, 2010.

Revised version accepted: July 13th, 2010.

\section{Addresses of the authors:}

René H.B. FraAiJe, Oertijdmuseum De Groene Poort, Bosscheweg 80, NL-5283 WB Boxtel, the Netherlands; e-mail: info@oertijdmuseum.nl

BARRY W.M. van BAKEL, Oertijdmuseum De Groene Poort, Boxtel, and Nederlands Centrum voor Biodiversiteit (Naturalis), P.O. Box 9517, NL-2300 RA Leiden, the Netherlands;

e-mail: barryvanbakel@gmail.com

JoHN W.M. JAGT, Natuurhistorisch Museum Maastricht, de Bosquetplein 6-7, NL-6211 KJ Maastricht, the Netherlands; e-mail: john.jagt@maastricht.nl

Frederik H. Mollen, Elasmobranch Research, Meistraat 16, B-25900 Berlaar, Belgium;

e-mail: frederik.mollen@telenet.be 